\title{
EXPLORATION OF LAND RESOURCES FOR ANALYSING THE SUITABILITY OF SELECTED CROPS IN AN ADMINISTRATIVE UNIT OF THRISSUR DISTRICT, KERALA
}

\author{
K. Shyju ${ }^{1, *}$, K. Kumaraswamy ${ }^{2}$ \\ ${ }^{1}$ Department of Geography, Kannur University, Kerala, India - shyjugeo86@gmail.com \\ ${ }^{2}$ Department of Geography, Bharathidasan University, Tamil Nadu, India - kkumargeo@gmail.com
}

Commission III, WG III/10

KEY WORDS: Soil Characteristics, Crops, Cartosat, GIS, Overlay Analysis, Land Suitability

\begin{abstract}
The fitness of land for a defined use is termed as land suitability. The aim of the study is to find the land suitability of for selected crops examining the indicators of land suitability. The study focuses on analysing suitability of agricultural crops in Pazhayannur Block of Thrissur District. Pazhayannur is the administrative unit (block) in the east of the Talapilli Taluk of Thrissur District in Kerala. The physical and chemical characteristics of the soils of Pazhayannur block like texture, depth, slope, erosion, $\mathrm{pH}$, salinity and soil available primary nutrients (NPK), secondary nutrients and micronutrients are identified. The slope of the terrain using Cartosat-Digital Elevation Model, soil erosion, rainfall and land capability is analysed for suitability classification. Land suitability is studied for the selected crops like paddy, banana, coconut, and rubber. The weighted overlay analysis in GIS is adopted for the analysis. The parameters are weighted based on its class and its influence in suitability of specific crops. The results on agricultural land suitability for individual crops were divided into 5 categories according to the land suitability classification of the United Nations Food and Agriculture Organization (FAO). It is identified that Pazhayannur has potential for the cultivation of the selected crops. The crops show high suitability (S1) in minor proportion and moderate suitability (S2) is found in 30 percent and above and marginal suitability (S3) is noticed in lesser areas. There is few portion of land which is currently not suitable for cultivation (N1) because of its topographic limitations. The restricted areas of forest are permanently not suited for agriculture (N2).
\end{abstract}

\section{INTRODUCTION}

The process of land suitability classification is the appraisal and grouping of specific areas of land in terms of their suitability for defined uses. The principle purpose of agriculture land suitability evaluation is to predict the potential and limitation of the land for crop production (Pan and Pan, 2012). Soil is the base for every production system and knowledge of their properties, extent and spatial distribution at watershed level is extremely important for developing land use (Sarkar et al., 2006). Information on the site characteristics, landforms, and quality of the soils has been recognized as an important requirement in the planning process for land suitability evaluation for different crops. Soil always develops in an organized manner on any given landform and a very close association exists between the different slope units of the landforms (Dent and Young, 1981). The study of soil-site characteristics for predicting the crop performance of an area forms land evaluation (Sehgal, 1991).

Crop land suitability analysis is a prerequisite to achieve optimum utilization of available land resource for agricultural production in a sustainable manner (Jadab Chandra Halder, 2013). Land use suitability analysis is the process of determining the suitability of a given land area for a certain type of use and the level of suitability is determined using the parameters like soil texture, organic matter content, soil depth, slope and land use/land cover (Akinci et al., 2013; Bandyopadhyay et al., 2009). Land evaluation by map analysis techniques may be accomplished with any geographical information system (Burrough, 1987) one of the most useful applications of GIS for planning and management is the land use suitability mapping and analysis (Collins et al., 2001). The overlay procedures play a central role in many GIS applications including techniques that are in the forefront of the advances in the land-use suitability analysis such as: multicriteria decision analysis (Diamond and Wright, 1988).

\section{STUDY AREA}

Pazhayannur is an administrative block in Talapilli Taluk in the north of Thrissur District. It is located in between $10^{\circ} 35^{\prime} 42^{\prime \prime} \mathrm{N}$ and $10^{\circ} 46^{\prime} 00^{\prime \prime} \mathrm{N}$ latitudes and $76^{\circ} 14^{\prime} 25^{\prime \prime} \mathrm{E}$ and $78^{\circ} 28^{\prime} 46^{\prime \prime} \mathrm{E}$ longitudes at an altitude of 400 metres MSL. The geographical area of Pazhayannur block is 233 sq.km and is bounded by Thrissur Taluk in the south, Palakkad District in the northeast and Wadakkanchery block in the west. The north of the block boundaries with Palakkad District is limited by the west flowing river from the Western Ghats called Bharathapuzha. Pazhayannur is the agriculture dominant area with higher proportion of wetlands. Natural vegetation is rich in Pazhayannur; forested area covers nearly 85 sq.km. The south and centre of the block is elevated and forested areas sloping towards north east and west. Pazhayannur block is well connected with the areas of Palakkad district because of the limitation of forested areas in the south restricting from connecting to its main administrative areas. 


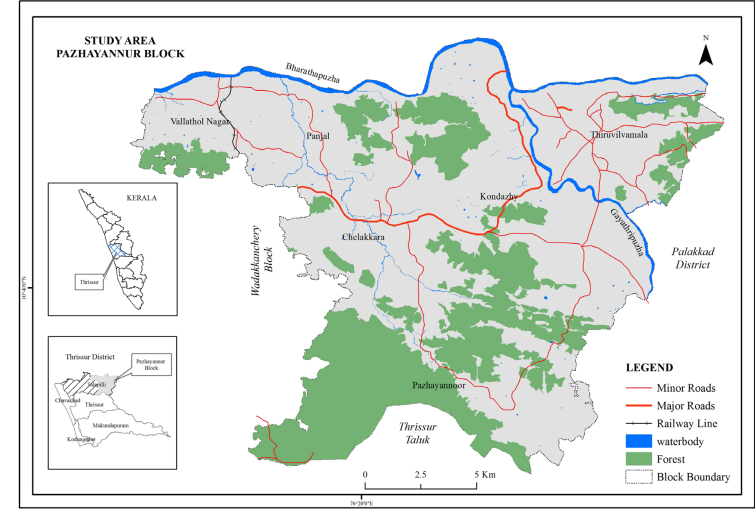

Figure 1. Location of the Study Area

\section{MATERIALS AND METHODS}

The agricultural land suitability of the study area is carried out by analyzing the physical and chemical parameters of the soil by adopting National Bureau of Soil Survey and Land Use Planning land suitability criteria. Soil data is collected from the Department of Soil Survey, Government of Kerala and the climatic data from Indian Meteorological Department, Remote sensing data collected from National Remote Sensing Centre, Hyderabad. The parameters used for the analysis are soil parameters like soil texture, depth, slope, erosion, soil nutrients, $\mathrm{pH}, \mathrm{EC}$ and drainage and climatic parameters like rainfall. The land suitability study for different crops is carried out using overlay analysis in GIS by assigning the weight to the spatial layers of selected parameters for evaluation by expert consultation, namely physicochemical characteristics of soils, climatic parameters and the topography. The obtained results are classified based on FAO land suitability class highly suitable (S1), moderately suitable (S2), marginally suitable (S3), currently not suitable (N1) and permanently not suitable (N2).

\section{RESULTS AND DISCUSSION}

\subsection{Land Suitability for Paddy}

Paddy is a wetland crop and a major cereal and food crop. Paddy is cultivated in the wetlands lands having gentle slopes, receiving rainfall of above $1000 \mathrm{~mm}$ with normal temperature of $30^{\circ}$ to $34^{\circ} \mathrm{C}$. The soils like clay, clay loam, silty clay, silty clay loam and sandy clay having imperfectly or poorly drained soils with negligible or slight erosion is favourable for paddy. The reaction status of the soil favourable for paddy is $\mathrm{pH} 5.5$ to 6.5 and salinity less than $3 \mathrm{dS} / \mathrm{m}$ with the soil depth of above 75 $\mathrm{cm}$ favouring rooting conditions. Paddy is the major wetland crop in the area and is cultivated by the majority of farmers from small scale to marginal scale. The land suitability study for paddy states that 21 percent of the total area is highly suitable (S1), Moderate suitability (S2) is noticed in 32 percentage of the total area. The marginal suitability (S3) is found in 17 percent of the area and 7 percent of the area is currently not suitable (N1) for paddy cultivation because of severe limitations.

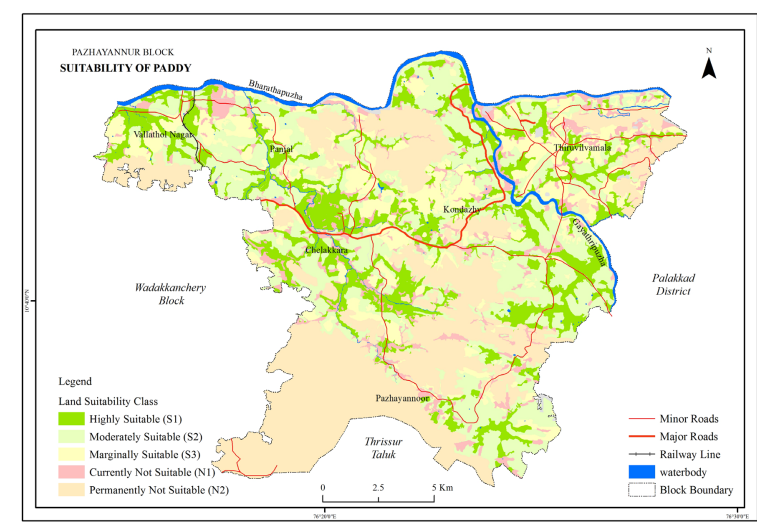

Figure 2. Land Suitability for Paddy Cultivation

\subsection{Land Suitability for Coconut}

Coconut is an important plantation crop. Coconut grows well in places having moderate slopes, receiving rainfall of above 1300 $\mathrm{mm}$ with normal temperature of $26^{\circ}$ to $29^{\circ} \mathrm{C}$. The soils like clay loam, sandy clay loam, sandy clay, silty clay loam, silty loam, with well drainability having negligible or slight erosion is favourable for coconut. The $\mathrm{pH}$ of soil ranging from 5.1 to 6.5 and soil having the depth of above $100 \mathrm{~cm}$ is favourable for growth and rooting of coconut. The land suitability study for coconut states that 13 percent of the area is highly suitable (S1). Moderate suitability (S2) is noticed in 52 percentage of the area. The marginal suitability (S3) is found in 5 percent and 8 percent of the area is currently not suitable (N1) for coconut cultivation because of severe limitations for sustained use.

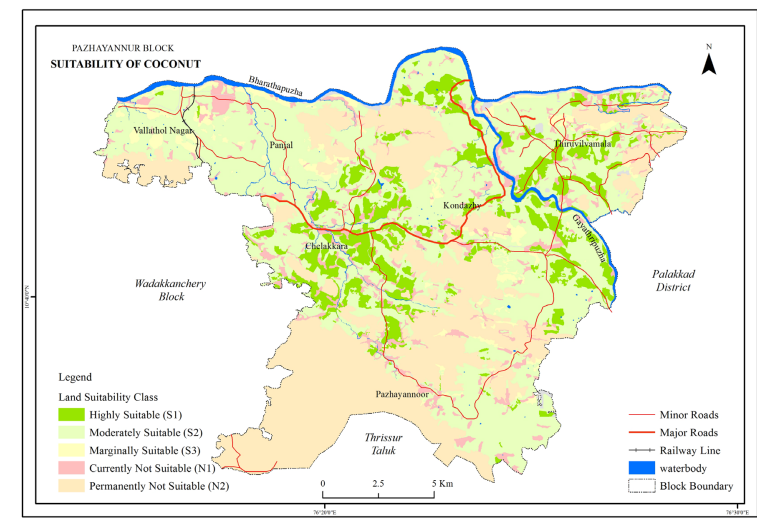

Figure 3. Land Suitability for Coconut Cultivation

\subsection{Land Suitability for Rubber}

Rubber is one of the important cash crops under plantation. It is cultivated mainly in garden lands because the wet lands have high limitations for its growth. Rubber is cultivated in the places where once the other crops like arecanut, coconut and coffee is cultivated because of its economic value. It could be cultivated well in areas receiving rainfall of above $1750 \mathrm{~mm}$ with normal temperature of $25^{\circ}$ to $30^{\circ} \mathrm{C}$. Rubber is cultivated well in sandy clay loam and loamy soils and it requires well drained soils for its growth. Soils having slight erosion or moderate is suitable for rubber having moderate to gentle slopes. The reaction of soil ranging from $\mathrm{pH} 4.5$ to 5.5 is favourable for rubber and soil having the depth of above 100 $\mathrm{cm}$ is good for rubber cultivation. The land suitability study for rubber states that 17 percent of the area is highly suitable (S1) 
for rubber cultivation. Moderate suitability (S2) is noticed in 34 percentage of the area having minor limitations for sustainable use. The marginal suitability (S3) is found in 18 percent having topography and drainage as major limitations. And 9 percent of the area is currently not suitable (N1) for rubber cultivation.

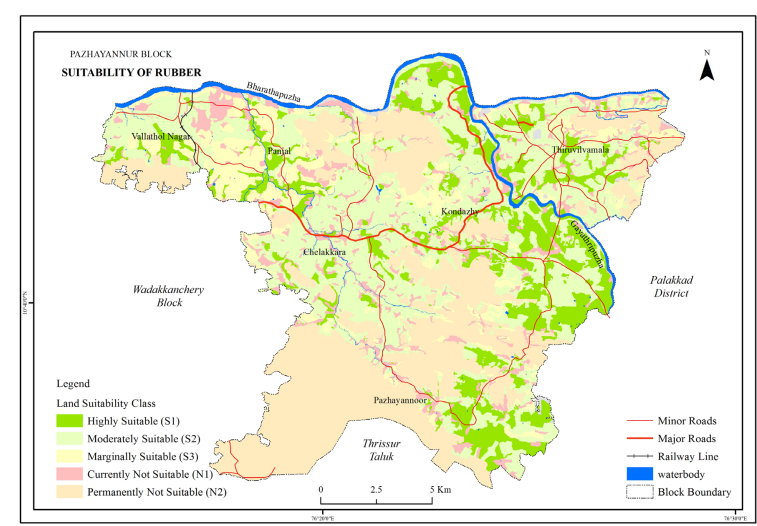

Figure 4. Land Suitability for Rubber Cultivation

\subsection{Land Suitability for Banana}

Banana is cultivated mainly in wet lands and converted wet lands. Banana is a water intensive crop and it could be cultivated well in areas receiving rainfall of above $100 \mathrm{~mm}$ per month and with normal temperature of $26^{\circ}$ to $33^{\circ} \mathrm{C}$ during its growing period. Banana is grown well in loam, clay loam, sandy clay loam and silty loam soils and it requires well drained soils for its growth. Soils having slight or nill erosion is suitable for banana having gentle slopes to nearly level lands. The $\mathrm{pH}$ ranging from 6.5 to 7.0 is favourable for banana and soil having the depth of above $125 \mathrm{~cm}$ is good for banana cultivation. The land suitability study for banana states that 25 percent of the area is highly suitable (S1) for banana cultivation. Moderate suitability (S2) is noticed in 29 percentage of the area. The marginal suitability (S3) is found in 12 percent. And 10 percent of the area is currently not suitable (N1) for banana cultivation because of severe limitations for sustained use.

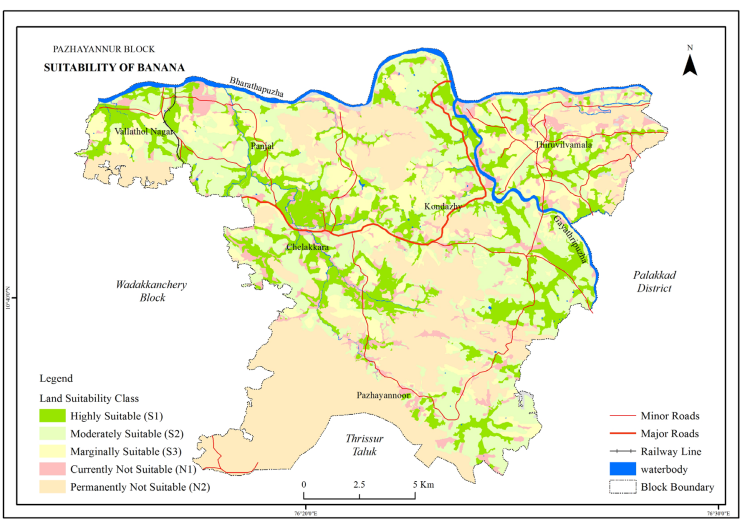

Figure 5. Land Suitability for Banana Cultivation

\section{CONCLUSION}

The land suitability analysis adopting FAO methodology and National Bureau of Soil Survey Classification Criteria for crop suitability is attempted in the study for major crops like coconut, rubber, paddy and banana. Paddy and banana shows highest suitability of above 20 percent of the land. Coconut and rubber shows 13 and 17 percentage of high suitability respectively. Moderate suitability (S2) covers larger areas for all the crops almost above 30 percent of the study area. Marginal suitability (S3) is seen in minor extent because most of the crops occupying less than 20 percentage of the total area. The currently not suitable (N1) lands are those lands which are temporarily converted wetlands. The permanently not suitable (N2) is nearly 23 percentage area of Pazhayannur which is the reserved forest areas restricted for agriculture.

\section{ACKNOWLEDGEMENT}

The authors gratefully acknowledge the financial support received from the University Grants Commission (UGC) under Basic Scientific Research Fellowship (BSR).

\section{REFERENCES}

Burrongh, P.A., (1987). Mapping and Map Analysis: New Tools for Land Evaluation. Soil Use and Management, 3, pp. 20 -25 .

Bandyopadhyay, S., Jaiswal, R.K., Hegde, V.S. and Jayaraman V., (2009). Assessment of Land Suitability Potentials for Agriculture Using A Remote Sensing and GIS Based Approach. International Journal of Remote Sensing, 30 (4), pp. 879 - 895.

Collins, M.G., Steiner, F.R. and Rushman M.J., (2001). LandUse Suitability Analysis in the United States: Historical Development and Promising Technological Achievements. Environmental Management, 28 (5), pp. 611 - 621.

Dent, D. and Young, A., (1981a). Soil Survey and Land Evaluation. Soil Use and Management, 7 (4), pp. 239 - 246.

Diamond, J.T. and Wright, J.R., (1988). Design of an Integrated Spatial Information System for Multi objective Land-Use Planning. Environment and Planning, 15 (2), pp. 205 - 214

FAO, (1976). A Framework for Land Evaluation. FAO Soil Bulletin No.32, Rome.

FAO, (2007). A Framework for Land Evaluation. FAO Soil Bulletin No.6, Rome.

Jadab Chandra Halder, (2013). Land Suitability Assessment for Crop Cultivation by Using Remote Sensing and GIS. Journal of Geography and Geology, 5 (3), pp. 65 - 74.

Pan, G., and Pan, J., (2012). Research in Crop Land Suitability Analysis Based on GIS. Computer and Computing Technologies in Agriculture, 3 (65), pp. 314 - 325.

Sarkar, D., Gangopadhyay, S. K., and Sahoo, A. K., (2006). Soil Resource Appraisal Towards Land Use Planning Using Satellite Remote Sensing and GIS - A Case Study in Patloinala Microwatershed, District Puruliya, West Bengal. Journal of the Indian Society of Remote Sensing, 34 (3), pp. 245 - 260.

Sehgal, J.L., (1991). Soil-Site Suitability Evaluation for Cotton. Agropedology, 1, pp. $49-63$

Shyju K and Kumaraswamy, K., (2017). A Study on Agricultural Land Use and Cropping Pattern in Talapilli Taluk, Thrissur District, Kerala. Research Expo 7 (6), pp. 40 - 53. 